\title{
Impact of Orgnizational Culture on Job Satisfaction in Selected Hospitals of Chandigarh Region
}

\author{
Dr. Renuka Mehra \\ Assistant Professor in Government College of Commerce and Business Administration, Sector- 50, Chandigarh.
}

\begin{abstract}
Organizations is a place where a candidate enter's it for employment purpose. But later his actions and words jointly by all the candidates make it a work place which later becomes culture. Employees care about their work and the work also depends upon the relationship which they share with their colleagues. Organizational culture is an effective control mechanism dictating employee behavior. The impact of good organizational culture will result in satisfied and committed employees in the organization. The present study made an attempt to study the impact of organizational culture on job satisfaction on a sample of 200 hospital employees located in Chandigarh Region. For analyzing purpose correlation and multiple regressions modelling technique has been used. The findings show a positive impact of organizational culture on overall job satisfaction in selected hospitals located in Chandigarh Region.
\end{abstract}

Keywords: Organizational culture, job satisfaction, hospitals.

DOI: $10.7176 / \mathrm{EJBM} / 11-10-09$

Publication date: April 30 2019

\section{Introduction}

Planning is blue print for work but it remains on papers until and unless it is performed by the right employee at the right time and at the right place. Employees are taught the way they need to present themselves before customers through organizational culture. Organizational culture covers a wide range of behaviour: the method of production, job skills and technical knowledge, attitudes towards discipline and punishment, the customs and habits of managerial behaviour, the objectives of the organization, its way of doing business, the method of payment, the value placed on different types of work, beliefs in democratic living and joint consultation, and the less conscious and taboos.

Culture or shared values within the organization may be related to increased performance. Researchers found a relationship between organizational cultures and company performance with respect to success indicators such as revenues, sales volume, market share, and stock prices. At the same time, it is important to have a culture that fits with the demands of the company's environment. Organizational culture is an effective control mechanism dictating employee behaviour. Culture is a more powerful way of controlling and managing employees' behaviours than organizational rules and regulations.

\section{NEED FOR THE PRESENT STUDY}

Culture is complex, elusive, and can be defined in many different ways. Organizational culture may be defined as deeply shared values and beliefs for integration, coordination and control to produce behavioural norms (Terblanche 2003, Baron 1999, Greenspan 1997, Sweeney 1994, and Gunter, 1993). Organizational culture is an idea in the field of organizational studies and management which describes the psychology, attitudes, experiences, beliefs, and values (personal and cultural values) of an organization. According to Hosfetede (1980), "Organizational culture is the specific collection of values and norms that are shared by people and groups in an organization and that control the way they interact with each other and with stakeholders outside the organization". This definition continues to explain organizational values, also known as, "beliefs and ideas about what kinds of goals members of an organization should pursue and ideas about the appropriate kinds or standards of behaviour organizational members should have to achieve these goals". From organizational values develop organizational norms, or expectations that prescribe appropriate kinds of behaviour by employees in particular situations, and control the behaviour of organizational members towards one another in every given situation.

Planning is the first step for the achievement of long-term vision of an organization. Managers only develop plan, they further communicate the plan for actual achievement to the employees of the organization. The primary issue arises when each and every organization has set beliefs, values, norms and procedures for their working, which are also known as organizational culture. When a candidate is selected for a job, organization person fit is considered, that means, are the values, beliefs the same as that of the candidate who desires to work (Schein 1996, Chatman 1988, and O'Reilley 1991). The following study can shed light on these questions.

Authors studied the impact of organizational culture on job satisfaction (Bigliardi 2012, Bellou 2010, Park and Kim 2009, Chang and Lee 2007, and Lund 2003). Also, organizational culture was found to be correlated with organizational commitment (Awan 2010, Kwates 2009, Lok et al., 2007, Wang 2007, William et al., 2007, and Sambasioan and Johari 2003). Results from the above stated studies revealed that a democratic, innovative 
and stable policy leads to a higher level of job satisfaction and organizational commitment among the employees. Also, inability to understand and manage organizational culture leads to wastage of time on irrelevant activities and can trigger conflict between different levels of the organization. It leads to cynicism and disillusionment among members of the organization. In the absence of any clear and defined organizational culture, the subsidiaries and departments within the organization may develop their own culture. The consequences of the above situation may lead to low level of production, poor quality output, and high cost of production. Also, complex culture leads to low job satisfaction and less committed employees. But a good and consistent organizational culture will lead to high level of job satisfaction, less labour turnover, and highly committed employees in the organization.

Conceptual Model for Research Objective 1

The following is the conceptual model developed for the present study:

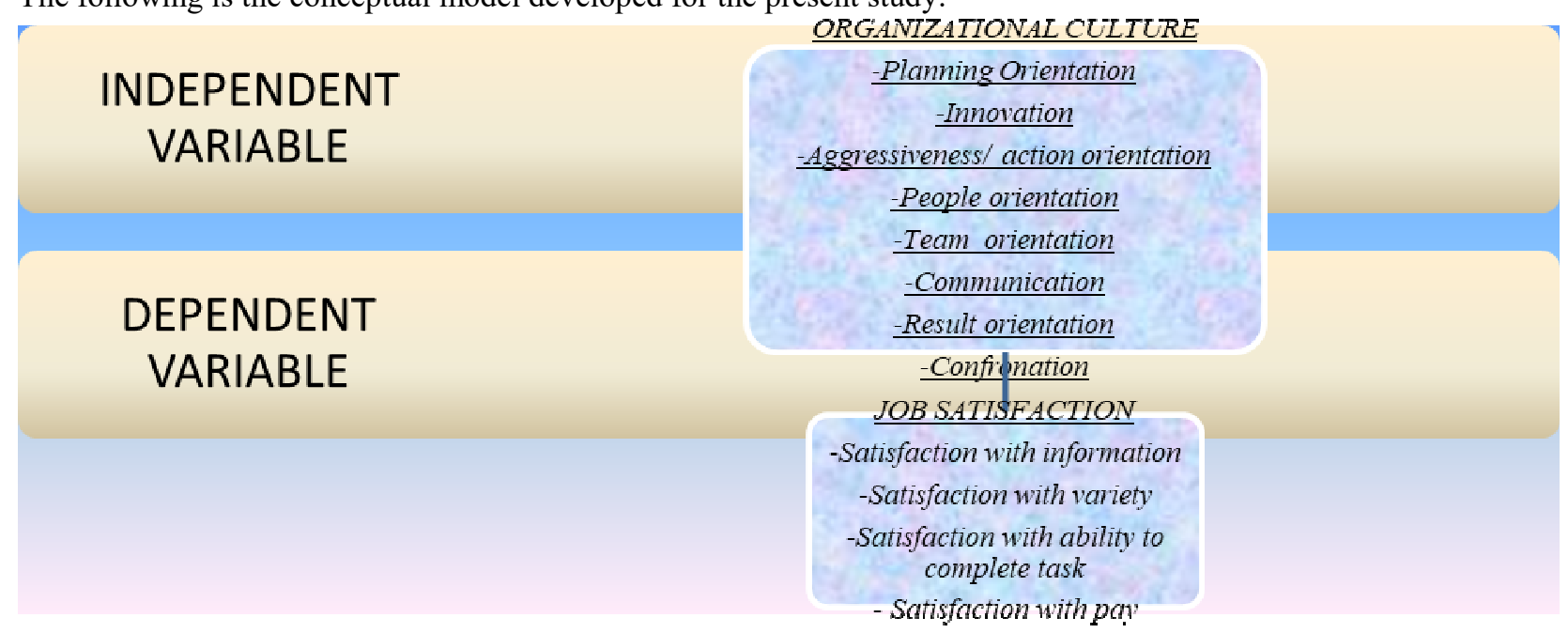

Source: Self Compilation based on Review of Literature.

Table 1: Review of Literature predicting the effect of organizational culture on job satisfaction

\begin{tabular}{|l|l|l|l|l|}
\hline Author & Country & Field & Major objectives & Major findings \\
\hline $\begin{array}{l}\text { Eskildsen } \\
(2010)\end{array}$ & U.K. & 22 nations & $\begin{array}{l}\text { Focus on relationship between } \\
\text { job satisfaction and national } \\
\text { culture }\end{array}$ & $\begin{array}{l}\text { The findings demonstrated that national } \\
\text { culture does influence the results of job } \\
\text { satisfaction }\end{array}$ \\
\hline $\begin{array}{l}\text { Kwantes } \\
(2009)\end{array}$ & U.S.A. & Engineers & $\begin{array}{l}\text { To compare and contrasted } \\
\text { role of organizational culture } \\
\text { and job satisfaction as } \\
\text { antecedents to organizational } \\
\text { commitment }\end{array}$ & $\begin{array}{l}\text { A strong relation was found between } \\
\text { collectivism on normative commitment. }\end{array}$ \\
\hline $\begin{array}{l}\text { Lund } \\
(2003)\end{array}$ & U.S.A & $\begin{array}{l}\text { Marketing } \\
\text { firms }\end{array}$ & $\begin{array}{l}\text { Examined the impact of } \\
\text { organizational culture on job } \\
\text { satisfaction }\end{array}$ & $\begin{array}{l}\text { Findings showed a positive relationship } \\
\text { between clan, adhocracy, and job } \\
\text { satisfaction }\end{array}$ \\
\hline $\begin{array}{l}\text { Lok and } \\
(2003)\end{array}$ & U.S.A. & $\begin{array}{l}\text { Hospitals } \\
\text { ( Nursing) }\end{array}$ & $\begin{array}{l}\text { Investigating relationship } \\
\text { between employees } \\
\text { perceptions of organizational } \\
\text { culture and job culture, job } \\
\text { satisfaction and commitment }\end{array}$ & $\begin{array}{l}\text { The paper suggested that managers } \\
\text { should give focus on sub cultures of } \\
\text { different nursing wards also. }\end{array}$ \\
\hline $\begin{array}{l}\text { Goserend } \\
(2003)\end{array}$ & U.S.A. & $\begin{array}{l}\text { Service } \\
\text { sector }\end{array}$ & $\begin{array}{l}\text { Had proposed a model having } \\
\text { antecedents moderators and } \\
\text { outcomes }\end{array}$ & $\begin{array}{l}\text { The findings showed that an employee } \\
\text { high on positive affectivity, low on } \\
\text { negative affectivity, and who feel } \\
\text { supported by their organizations are } \\
\text { anging high job satisfaction }\end{array}$ \\
\hline
\end{tabular}

Bigliardi (2012) examined the impact of organizational culture on the job satisfaction of knowledge workers in pharmaceutical industry. The study had two main objectives, the first was to test relationship between organizational culture and job satisfaction of knowledge workers and the second one was to investigate and locate which are those dimensions that lead to strong impact on job satisfaction in pharmaceutical industry. The result revealed that bureaucratic organizational culture had a negative impact on job satisfaction, while innovation or supportive dimension had positive impact.

Erkildseb et al., (2010) aimed to focus on the relationship between national culture and job satisfaction. Review 
of literature showed the research gap- that studies had focused on job satisfaction and national culture relationship between different counties, but neither of the researchers had compared two counties national culture through primary data analysis. The current study has attempted to relate data from the European Employees Index, the Hofstede's national score on four dimensions (Power distance, Individualism versus collectivism, Masculinity versus femininity and Uncertainty avoidance) of national culture. The analysis covered more than 25,000 employees from 22 national. The findings did not show any significant relationship between National culture and the results of job satisfaction studies.

Joo and Park (2010) investigated the impact of personal characteristic such as goal orientation, organizational learning culture, and development feedback on employee's carrier satisfaction, organizational commitment, and turnover intentions. The result indicated that career satisfaction was predicted by organizational learning culture and performance goals orientation. Organizational commitment was predicted by organizational learning culture, development feedback and performance goal orientation. Hierarchical multiple regression analysis showed that turnover intention was strongly predicted by organizational learning culture, career satisfaction and organizational commitment.

Bellou (2010) examined the impact of organization culture on employee's job satisfaction, taking into account their age and gender. Sample respondent were 125 employees from three public hospitals located in Greece City. Dimensions such as fairness, opportunities for personal growth, enthusiasm for the job and good reputation for the job were found to be strongly associated with organizational culture. But on the other hand, negative association was found between aggressiveness dimension of organizational culture and job satisfaction. Results of t-test revealed that employee's gender and age influence the way in which organizational culture affects job satisfaction in hospital.

The table 1 shows number of studies on the both variables jointly in foreign countries. Almost no research was found in Indian scenario. The present paper has made an attempt to show the relationship in India.The need for conducting the present study, "Impact of organizational culture on job satisfaction in selected Hosiptals of Chandigarh Region" has been summarized in the following three points:

1. To examine the interaction of employees with customers through face to face interactions.

2. To examine the relationship of employer and employee under Sec15 (2) of Salary under the Income Tax Act, 1961 exists between the above two. If the employee works under the control and supervision of Employer and in words Employer is said to control the action and functions of the employee.

3. To examine employee's performance on the basis of frequent interaction with customers and other employees in routine work in a given culture.

\section{HOSPITAL SERVICE ORGANIZATIONS - AN OVERVIEW}

The WHO constitution defines health as a 'state of complete physical, mental and social well-being and not merely the absence or infirmity.' The art of medical care in India was introduced 3500 years ago. Healthcare in India is the responsibility of constitutes states and territories. The Ministry of Health every year lays down norms for health care for the citizens. The health care industry has been witnessing an increase in numbers of patients not only from India but also from abroad.

Table 2: Statistics showing enrolment of students in health care colleges

\begin{tabular}{|l|l|}
\hline Total number of medical colleges in India & 335 colleges \\
\hline All India medical seats & 41,569 \\
\hline
\end{tabular}

Source:http://zeenews.india.com/news/nation/govt-to-double-availability-of-medical-seats_775336.html. Source: Deewan (2010), "Exploring quality of work life among doctors in select Hospitals in Chandigarh", Unpublished Thesis, University Business School, Panjab University.

Challenges Faced by Employees in Hospital Service Organizations

\begin{tabular}{|ll|l|}
\hline 1) & Growing Health Care Sector & 5) Rise of diseases \\
\hline 2) & Growing population of the economy & 6) Deteriorating infrastructure \\
\hline 3) & Expanding middle class & 7) Brain Drain Problem \\
\hline 4) & Rise in income level of consumers & 8) Salary and other emoluments \\
\hline
\end{tabular}

\section{GEOGRAPHIC SCOPE OF THE PRESENT STUDY}

The geographical scope of the present study includes Chandigarh, a planned city, a union territory, and the capital to two states, viz. Punjab and Haryana, Mohali, city from Punjab and Panchkula, city from Haryana, also known as Chandigarh Capital Region. The area has been selected by the researcher on the basis of judgement and convenience.

\section{OBJECTIVES OF THE STUDY}

1. To examine the relationship between organizational culture and job satisfaction among employees in selected Hospitals in Chandigarh region. 
2. To suggest Hospitals organization manager's strategies to reduce organizational culture and leading to a committed work force.

\section{HYPOTHESES OF THE STUDY}

$\mathrm{H}_{1}$ shows the assumptions regarding the relationship between eight dimensions of organizational culture, namely with job satisfaction.

H1: All the four dimensions of organizational culture predicts job satisfaction in Hospitals.

$\mathrm{H}_{1 \mathrm{a}}$ : Planning orientation has a significant impact on job satisfaction.

H1b: Innovation has a significant impact on job satisfaction.

H1c: Aggressiveness/ action orientation has a significant impact on job satisfaction.

H1d: People orientation has a significant impact on job satisfaction.

He: Team orientation has a significant impact on job satisfaction.

H1f: Communication has a significant impact on job satisfaction.

H1g: $\quad$ Result orientation has a significant impact on job satisfaction.

$\mathrm{H}_{1 \mathrm{~h}}$ : Confrontation has a significant impact on job satisfaction.

\section{RESEARCH METHODOLOGY}

Survey method of research was used to conduct the study. Four Hospitals namely, 1) GMHC -16 (Government Hospitals), 2) GMHC-32 (Government Hospital) , 3) Fortis Hospital (Private) and 4) Alchemist (Private Hospital), were the sample organizations for the study. A total of 200 employees working in the stated hospital service organization became the sample respondents. The paper had two variables, independent one was organizational culture and the dependent variable was job satisfaction. Organizational culture scale included items that represented the eight dimensions using the Survey of management Climate (Gordon and Cummins, (1979) and job satisfaction includes items described by using the scale developed by Wood et al., (1976). Demographic information was collected through questions on gender, age, education, experience and income. Analysis was performed using SPSS Version 16.0. For testing the objectives, tools such as Pearson Correlation and Multiple- regression were used in the study.

RESULTS AND DISCUSSION :Table 3: Profile of Respondents

\begin{tabular}{|c|c|c|}
\hline 1.Gender & Frequency & Percentage (\%) \\
\hline Male & & $\%$ \\
\hline Female & & $\%$ \\
\hline $\mathrm{n}=$ & 200 & $100 \%$ \\
\hline \multicolumn{3}{|l|}{ 2.AGE } \\
\hline \multicolumn{3}{|l|}{ Below 20 year } \\
\hline Between 20-34 & & $\%$ \\
\hline Between 35-54 & & $\%$ \\
\hline 35 and above & & $\%$ \\
\hline $\mathrm{n}=$ & 200 & $100 \%$ \\
\hline \multicolumn{3}{|l|}{ 3.Education } \\
\hline $10^{\text {th }}-12^{\text {th }}$ & & $\%$ \\
\hline Under-graduates & & $\%$ \\
\hline Graduates & & $\%$ \\
\hline Post graduates & & $\%$ \\
\hline $\mathrm{n}=$ & 200 & $100 \%$ \\
\hline \multicolumn{3}{|l|}{ 4.Expereince } \\
\hline Less than 5 years & & $\%$ \\
\hline 5 years- 10 years & & $\%$ \\
\hline 10 years and above & & $\%$ \\
\hline $\mathrm{n}=$ & 200 & $100 \%$ \\
\hline \multicolumn{3}{|l|}{ 5. Income } \\
\hline Less than ₹3 lak & & $\%$ \\
\hline Between ₹3lak-₹6 lak & & $\%$ \\
\hline 6 lak Above and above & & $\%$ \\
\hline $\mathrm{n}=$ & 200 & $100 \%$ \\
\hline
\end{tabular}

Table 1 represents the profile of respondents who participated in the study. As it can be seen from the Table 1 , the percentage of male respondents is $57 \%$ that are 114 out of 200 whereas there are $43 \%$ female respondents that are 86 out of 200 . In age $81(40.5 \%)$ of respondents are between the age group of 35-54 years. There are 127 
$(63 \%)$ respondents who are Graduates, $61(31 \%)$ are Post graduates, $08(4 \%)$ are qualified to senior secondary level and only $02(04 \%)$ respondents are Under-graduates. Out of 200 respondents, $89(44.5 \%)$ respondents have more than 10 year experience, $60(30 \%)$ respondents have experience below 5 years and rest of the 51(25.5\%) respondents has experience between 5-10 years. Further Experience demographic profile show that $73(36.5 \%)$ have income between ₹ 3 Lakhs- ₹ 6 Lakhs, 69(34.5\%) respondents earned less than ₹ 3 lakhs while $23.5 \%$ of the employees had earning above $₹ 6,00,000$.

\section{DESCRIPTIVE STATISTICS}

Table 2: Mean and Standard Deviation

\begin{tabular}{|l|l|l|l|}
\hline S.No. & Dimensions & Mean & Standard Deviation \\
\hline 1 & Planning orientation & $\mathbf{3 . 9 1}$ & $\mathbf{0 . 6 0}$ \\
\hline 2 & Innovation & $\mathbf{3 . 8 9}$ & $\mathbf{0 . 6 0}$ \\
\hline 3 & Aggressiveness/ action orientation & $\mathbf{3 . 8 6}$ & $\mathbf{0 . 5 3}$ \\
\hline 4 & People orientation & $\mathbf{3 . 8 9}$ & $\mathbf{0 . 5 8}$ \\
\hline $\mathbf{5}$ & Team orientation & $\mathbf{3 . 9 0}$ & $\mathbf{0 . 5 9}$ \\
\hline 6 & Communication & $\mathbf{3 . 8 9}$ & $\mathbf{0 . 5 2}$ \\
\hline 7 & Result orientation & $\mathbf{3 . 9 4}$ & $\mathbf{0 . 5 3}$ \\
\hline $\mathbf{8}$ & Confronation & $\mathbf{3 . 9 2}$ & $\mathbf{0 . 5 7}$ \\
\hline 9 & Job satisfaction & $\mathbf{3 . 8 6}$ & $\mathbf{0 . 5 8}$ \\
\hline
\end{tabular}

Table 2 presents the Mean and Standard Deviation of all the observed variables for employees of selected hospitals organization. An investigation of table 2 reveals that the mean score of organizational culture dimensions are found to be 31.2 for respondents with SD 4.52 It also demonstrations that mean score of job satisfaction dimensions is 3.86 with SD 0.58. It shows that the scores on organizational culture and job satisfaction variables scores ranges from average to above average but normal.

Table 3 Correlation - Organizational Culture Dimensions and Job Satisfaction for selected Hospitals Organizations

\begin{tabular}{|l|l|l|l|l|l|l|l|l|}
\hline & $\begin{array}{l}\text { Planning } \\
\text { orienta- } \\
\text { tion }\end{array}$ & $\begin{array}{l}\text { Innova- } \\
\text { tion }\end{array}$ & $\begin{array}{l}\text { Aggressive- } \\
\text { ness/ action } \\
\text { orient-tation }\end{array}$ & $\begin{array}{l}\text { People } \\
\text { orient- } \\
\text { tation }\end{array}$ & $\begin{array}{l}\text { Team } \\
\text { orient- } \\
\text { tation }\end{array}$ & $\begin{array}{l}\text { Communi- } \\
\text { cation }\end{array}$ & $\begin{array}{l}\text { Result } \\
\text { orient- } \\
\text { tation }\end{array}$ & $\begin{array}{l}\text { Confron- } \\
\text { tation }\end{array}$ \\
\hline $\begin{array}{l}\text { Job } \\
\text { satisfaction }\end{array}$ & $0.419^{*}$ & $0.218^{*}$ & $0.347^{*}$ & $0.458^{*}$ & $0.372^{*}$ & $0.351^{*}$ & $0.407^{*}$ & $0.141^{*}$ \\
\hline
\end{tabular}

1)Pearson Correlation

2)*Correlation significant at .05 level

The relationship between organizational culture dimensions and job satisfaction is investigated by using Karl Pearson correlation. The preliminary analysis reveals that there was no violation of the assumptions of linearity and homoscedasticity, and all associations are found to be significant at 95 percent level, with strongest association between job satisfaction and people orientation $(\mathrm{r}=0.458, \mathrm{p} \leq 0.05)$ followed by planning orientation $(\mathrm{r}=0.419, \mathrm{p} \leq 0.05)$. It can be inferred that employees design their work in a team oriented manner. They also agree that in order to meet the hospital requirements, they plan their action first and a strong association is found with overall job satisfaction.

Table 4:Multiple Regression Model Summary and Multicollinearity Diagnostics-Impact of Organizational Culture on Job Satisfaction for Hospital Organizations

\begin{tabular}{|l|l|l|l|l|l|l|}
\hline Independent Variable & & $\begin{array}{l}\text { Standardized } \\
\text { Regression } \\
\text { Coefficients }\end{array}$ & $\begin{array}{l}\text { T- } \\
\text { value }\end{array}$ & Sig. & $\begin{array}{l}\text { Tolerance } \\
\text { value }\end{array}$ & $\begin{array}{l}\text { Variance } \\
\text { inflation factor }\end{array}$ \\
\hline Constant & & & 5.320 & 0.000 & & \\
\hline People orientation & & 0.301 & 4.447 & 0.000 & 0.755 & 1.325 \\
\hline Result orientation & & 0.263 & 4.153 & 0.000 & 0.862 & 1.159 \\
\hline Planning orientation & & 0.179 & 2.564 & 0.011 & 0.709 & 1.411 \\
\hline Multiple $\boldsymbol{R}$ & 0.566 & & & & & \\
\hline $\mathbf{R}^{\mathbf{2}}$ & 0.320 & & & & & \\
\hline $\mathbf{a d j u s t e d ~ R}^{\mathbf{2}}$ & 0.310 & & & & & \\
\hline F & 30.813 & & & $\mathbf{0 . 0 0 0}$ & & \\
\hline Sample Size & $\mathbf{2 0 0}$ & & & & & \\
\hline
\end{tabular}

1)Independent variable : dimensions of organizational culture

2)Dependent variable: job satisfaction

$3) \mathrm{R}^{2}$ refers to the coefficient of determination that measures the proportion of the variance in the dependent variable that explained by the independent variables. 
Table 4 also shows multiple regression analysis and multicollinearity diagnostics for Job satisfaction. It shows that variables, viz. planning orientation $(\beta=0.179, p \leq 0.05)$, people orientation $(\beta=0.301, p \leq 0.05)$, and result orientation $(\beta=0.263, \mathrm{p} \leq 0.05)$ are strong drivers of job satisfaction. However, it can be observed that employees expect three out of eight organizational culture dimensions as strong base for work performance and on receiving these variables employees will feel satisfied with overall job provided in Hospital Service Organizations. It can be inferred that employee's satisfaction is the outcome of well defined plans, growth of doctors, nurses, and other medical staff members from within hospital and highly interactive behaviour of the employee towards patients and their attendants.

The value of the variance inflation factor (VIF) and tolerance value (TV) for linear multiple regression model is presented in Table 4. As indicated in Table 5.34 the value of VIF, which served as an indicator of multicollinearity, ranges between 1.159-1.411, far below the cut-off value of 10. Besides, it can be seen that the tolerance value for each independent variable is closer to one that points out that there is no evidence of multicollinearity problem in the multiple regression model as shown.

\section{Hypotheses Testing for $\mathrm{H}_{1}$}

It can therefore be concluded from the above results that Hypotheses $\mathrm{H}_{1 \mathrm{a}}, \mathrm{H}_{1 \mathrm{~b}}, \mathrm{H}_{1 \mathrm{c}}, \mathrm{H}_{1 \mathrm{~d}}, \mathrm{H}_{1 \mathrm{e}}, \mathrm{H}_{1 \mathrm{f}}, \mathrm{H}_{1 \mathrm{~g}}$ and $\mathrm{H}_{1 \mathrm{~h}}$ are partially accepted and partially rejected. Hypotheses $\mathrm{H}_{1 \mathrm{a}}, \mathrm{H}_{1 \mathrm{~d}}$ and $\mathrm{H}_{1 \mathrm{~g}}$ are supported and hypotheses $\mathrm{H}_{1 \mathrm{~b}}, \mathrm{H}_{1 \mathrm{c}}, \mathrm{H}_{1 \mathrm{e}}$, $\mathrm{H}_{1 \mathrm{f}}$ and $\mathrm{H}_{1 \mathrm{~h}}$ are rejected. It is revealed that the dimension of people orientation has a strong significant impact on job satisfaction in Hospitals Organizations.

\section{LIMITATIONS}

1. The first limitation concerns the nature of the measures used. The measures included in this research were based upon the perceptions of the employees of hospital organizations. Therefore, the potential for data inaccuracies due to item misinterpretation or predisposition to certain responses on the part of the participant does exist.

2. Responses have been solicited from the employees of selected hospitals located in Chandigarh Region. The perception of people in Chandigarh may vary from those of the rest of India.

3. There were only four hospitals whose employees participated in this study. As a result, the generalisation of the findings of this research should be considered carefully.

4. The data was collected during the working hours from the respondents. As a result, respondents might not have been able to give all correct answers due to their engrossment in work.

5. The data was fed into an excel sheet first. There exists a probability of wrong entry of data into the excel sheet while recording the responses of 200 respondents.

\section{IMPLICATIONS FOR THE MANAGERS}

1) According to the employees, targets are fixed by the top management and communicated to them through their managers. They say that they should also have the right to discuss the concerns related to their job profile, as an employee converts the blue print of organizations' vision and employees put their best to achieve it.

2) Another way is to let the employees know that the organization cares for their well-being. For example, planning orientation, people orientation, team orientation, and communication and result orientation, all dimensions of organizational culture showed strong significant impact on job satisfaction.

3) Another way is to let the employees know that the organization cares for their well-being. For example, planning orientation, people orientation, team orientation, and communication and result orientation, all dimensions of organizational culture showed strong significant impact on job satisfaction.

\section{CONCLUSION}

The research work provides a comprehensive model which can be used to understand and explain what influences the organizational culture and job satisfaction in the hospitals service organization. It cannot be claimed that the factors that the present research investigated are the only ones which influence job satisfaction. However, the study provides a starting point for future investigation. In terms of the relationship between the eight dimensions of organizational culture, and job satisfaction, adjusted $\mathrm{R}^{2}=31.0$ percent was statistically significant. All the eight dimensions, namely planning orientation, innovation, aggressiveness/ action orientation, team orientation, people orientation, communication, result orientation and confrontation were statistically significant at 95 percent. In addition, people orientation, planning orientation and result orientation had the greatest influence on job satisfaction. No problem of multicollinearity was detected.

As stated in chapter research, the primary data was collected from four hospitals located in Chandigarh region. It was observed by the researcher that employees of the hospital were engaged in different types of jobs. The first one is attending new cases, second one is attending patients who were already admitted into the hospital for treatment of their ailment and third one is attending emergency problems. 
According to Deal and Kennedy (1980), "Culture is a system of informal rules that spells out how people are to behave most of the time. Similarly in the above three situation doctors, nurses and other medical staff members attended to the ailment of patients as they were broken machines and need repair.

The above of observed finding were found to be correlated with actual results from the study. It means that employees are informed about the goals, their shifts in hospital and other activities. Hospital employees were given opportunities for their individual growth and development. In hospital alone, doctor or nurse or other medical staff member cannot do anything. Hence, the culture of the hospital made clear understanding about the inter relationship of their own jobs with those of others. Also, culture made employees personally responsible for the achievement or failure of the end results. The study was found to be supported by Erkildseb 2010, Kwates 2009, Rao and George 2009, and Chatman 1991.

\section{REFERENCES}

Agyris, C. (1959). The Individual and Organization: An Empirical Test. Administrative Science Quarterly 4 , $145-167$.

Alchemist Hospital. (2019). Retrieved January 5, 2019, from http://www.alchemisthospitals.com/

Arnold, D. R., Capelia, L. M., and Sumrall, D. A. (1987). Organization culture and the marketing concept: diagnostic keys for hospitals. JHCM, 7,18-28.

Artz, B. (2010). Fringe benefits and job satisfaction. International Journal of Manpower, 31,626-644.

Berg, P.T.V.D., and Wilderom, C.P.M. (2004). Defining, measuring, and comparing organizational cultures. Applied Psychology: An International Review, 53,570-582.

Bernal, J. G. B., Castel, A., Navarro, M. M. and Torres, P. R. (2005). Job satisfaction: empirical evidence of gender differences. Women in Management Review, 20, 279-288.

Buch, K., and Wetzel, D. K. (2001). Analyzing and realingning organizational culture. Leadership and Organizational Development Journal, 20, 40-44.

Carmeli, A. (2005). The relationship between organizational culture and withdrawal intentions and behaviour. International Journal of Manpower, 26, 177-195.

Central Bureau of Health Intelligence India. Retrieved 14 ${ }^{\text {th }}$ March, 2019 from http://cblidghs.nic.in/writereaddata/linkage/11\%20health\%20Infrastructure8356493923.pdf.

Chatman, J.A. (1991). Matching people and organizations: selection and socialization in public accounting firms. Administrative Science Quarterly, 37, 459-485.

Chandigarh. (2011). Retrieved January 5,2019, from http://en.wikipedia.org/wiki/Chandigarh

Fortis Hospital. (2012). Retrieved March 5, 2019, from http://www.fortishealthcare.com/

Government Medical College and Hospital (n.d.). Retrieved March 5, 2019, from http://www.gmch.gov.in/

Government Speciality Hospital (2012, 13 June). Retrieved March 15, 2019, from http://chandigarh.gov.in/

Indian Health Care Industry. Retrieved $\quad$ March, 2019 from http://www.indianhealthcare.in/index.php?option=comcontnentview $=$ article $\&$ catid $=131 \&=168 \% 2 \mathrm{AIndian}+$ Healthcare:+The+Growth+story .

Indian Hospital Best practices survey study Highlights Challenges and Opportunities. Retrieved March, 2019 from http://www.agroupllic.com/IHBP_Survey.pdf .

Kanousi, A. (2005). An empirical investigation of the role of culture on service recovery expectations. Managing Service Quality, 15, 57-69.

Lu, H., While, A. E., and Barriball, L. (2004). Job satisfaction among nurses: a literature review. International Journal of Nursing Studies, 42, 211-227.

Mannion, R., Davies, H. T. O. and Marshall M.N. (2005). Cultural characteristics of "high" and "low" performing hospitals. Journal of Health Organization and Management, 19, 431-439.

Shah, J. (2007). Organizational Culture and Job satisfaction: An Empirical study of R. and D. Organizations. SSRN, abstract-1293922, 1-13.

Walia,R.J., and Gupta, S. K. (2007). Organizational Behaviour. Chandigarh: Kalyani Publishers.

Zikmund, W. G. (2005). Business Research Methods. Bangalore: Thomas Asia Pte Ltd. 